\title{
Effect of trans-10, cis-12 conjugated linoleic acid on performance, adipose depot weights, and liver weight in early-lactation dairy cows
}

\author{
D. von Soosten, ${ }^{\star}$ U. Meyer, ${ }^{\star}$ E. M. Weber, $\dagger$ J. Rehage, $†$ G. Flachowsky, ${ }^{\star}$ and S. Dänicke ${ }^{\star 1}$ \\ *Institute of Animal Nutrition, Friedrich-Loeffler-Institute (FLI), Federal Research Institute for Animal Health, Bundesallee 50, \\ 38116 Brunswick, Germany \\ †Clinic for Cattle, School of Veterinary Medicine Hanover, 30173 Hanover, Germany
}

\section{ABSTRACT}

In feeding practice, conjugated linoleic acid (CLA) supplements are used to decrease milk fat excretion in early-lactation dairy cows to save energy to counteract the physiological negative energy balance. The present study was conducted to examine the effects of CLA on energy metabolism, changes in liver weight, and the weight of different adipose depots during early lactation. Primiparous lactating German Holstein cows $(\mathrm{n}=25)$ were divided into 5 groups and each group contained 5 animals. The experiment started $21 \mathrm{~d}$ prepartum and continued until $105 \mathrm{~d}$ in milk (DIM). Cows were slaughtered at 1,42 , and 105 DIM. The experiment was divided into a prepartum period (21 d prepartum until calving), period 1 (1 until 42 DIM), and period 2 (>42 until 105 DIM). In the prepartum period, all animals were housed together and fed the same diet with no CLA supplementation. At 1 DIM, an initial group, with no CLA supplementation, was slaughtered. The 20 remaining cows were assigned to 2 diets. One group received $100 \mathrm{~g} / \mathrm{d}$ of a control fat supplement $(\mathrm{CON} ; \mathrm{n}=10)$ and the other group 100 $\mathrm{g} / \mathrm{d}$ of a CLA supplement (CLA; $\mathrm{n}=10)$ from 1 DIM until slaughter. Five cows of each feeding group were slaughtered after 42 DIM and the remaining animals after 105 DIM. The CLA supplement contained approximately $10 \%$ each of trans-10, cis-12 CLA and cis-9, trans-11 CLA. During the slaughter process the empty body weight was recorded and the omental, mesenteric, retroperitoneal, and s.c. adipose depots, as well as the liver, were dissected and weighed. The CLA treatment decreased milk fat content in period 1 (14.1\%). In period 2, milk fat content $(25.4 \%)$ and yield (17.1\%) were lower in the CLA group. No effect of CLA on milk yield was observed. The net energy intake, milk energy output, and the calculated energy balance remained unchanged by CLA supplementation. No effect

Received September 22, 2010

Accepted February 18, 2011.

${ }^{1}$ Corresponding author: Sven.Daenicke@fli.bund.de of CLA on the weights of liver, omental, mesenteric, or s.c. adipose depots was observed when related to empty body weight. Liver weight increased with DIM, whereas the retroperitoneal adipose depot weight decreased at the same time. Compared with the initial group, the retroperitoneal adipose depot weight for control animals slaughtered after 42 DIM was decreased (47.7\%); however, for the CLA group slaughtered after 42 DIM, a trend to a lower retroperitoneal adipose depot weight (34.0\%) was observed. This suggests a CLA-induced deceleration of mobilization of the retroperitoneal adipose depot during the first 42 DIM.

Key words: conjugated linoleic acid, dairy cow, adipose depot, energy balance

\section{INTRODUCTION}

High energy demands of the mammary gland in early lactation of dairy cows with concomitant inadequate DMI lead to a negative energy balance (Bell, 1995). Milk fat represents $50 \%$ of the total milk energy and is the greatest proportion of milk energy output (Tyrrell and Reid, 1965). Thus, a decrease in milk fat excretion provides the opportunity for saving energy. The trans-10, cis-12 conjugated linoleic acid (CLA) isomer induces milk fat depression (MFD) by inhibiting the synthesis of milk fat (Baumgard et al., 2000). During MFD, milk fat content and yield are decreased and CLA is used with the intention to save energy and improve the energy balance. Several studies demonstrated that in early lactation, milk fat is decreased, but milk energy output is not affected due to the propensity to increase milk yield. Energy is repartitioned to milk yield and CLA has mostly no effect on calculated energy balance (Bernal-Santos et al., 2003; Bauman et al., 2008). For the duration of a negative energy balance the mobilization of body reserves from adipose tissue is needed to cover the energy requirements (Bauman and Currie, 1980). The effects of the trans-10, cis-12 CLA isomer on adipose depot weights in dairy cows are not clear. Current studies on cows during MFD showed that the trans-10 cis-12 isomer increases the abundance 
of mRNA for the expression of lipid synthesis genes of key enzymes involved in lipid synthesis in adipose depots (Harvatine et al., 2009). Then again, studies on mice indicated that the trans-10, cis-12 isomer decreases adipose depots and enlarges the liver (DeLany et al., 1999; Tsuboyama-Kasaoka et al., 2000; Clément et al., 2002; Degrace et al., 2003; Wang and Jones, 2004; Jaudszus et al., 2010). These different results could be linked with the different contribution of the liver and adipose depots to fatty acid synthesis in ruminants and rodents. Furthermore, the ruminant has other major sources of $\mathrm{C}$ for fatty acid synthesis, like acetate from ruminal fermentation (Pearce, 1983). These known differences in fat metabolism of ruminants and rodents make it necessary to investigate the development of adipose depots and liver weights under CLA-induced MFD during early lactation in dairy cows. Therefore, the present study was conducted to examine the effects of CLA supplementation on milk production, energy partitioning, and the weights of liver and adipose depots in early-lactation dairy cows.

\section{MATERIALS AND METHODS}

\section{Animals, Experimental Design, and Feeding}

In compliance with the European Union Guidelines concerning the protection of experimental animals, the study was conducted at the experimental station of the Institute of Animal Nutrition, Friedrich-Loeffler-Institute (FLI), Brunswick, Germany, and was approved by the Lower Saxony State Office for Consumer Protection and Food Safety (LAVES), Oldenburg, Germany (File Number 33.11.42502-04-071/07). To exclude possible effects from preceding lactations on adipose depots and the liver, only primiparous cows were used in the present trial. Twenty-five late pregnant heifers of the German Holstein breed were assigned to 5 groups with different slaughter times and feeding treatments. Four sires were involved in breeding of the animals used. Twenty animals originated from the same father and were evenly distributed over the 5 groups. All cows were born at the experimental station of the Institute of Animal Nutrition (FLI) and reared under the same conditions (equal housing and feeding). The first parturition was at an average age of $23 \pm 0.2$ mo. The experiment started $21 \mathrm{~d}$ prepartum and continued until 105 DIM. The animals were assigned to the 5 groups by considering the $\mathrm{BW}$ measured 3 wk before expected parturition. The experiment was divided into 3 periods according to the slaughter times at 1, 42, and 105 DIM. The prepartum period (21 d prepartum until calving), period 1 (1 until 42 DIM), and period 2 (>42 until 105 DIM). At the first slaughter time, 5 animals of an initial group (IG) were slaughtered, whereas 20 animals were assigned to a control (CON) or CLA-supplemented (CLA) diet. The CLA supplementation started at 1 DIM and continued until the slaughter. After 42 DIM, 5 animals of the control (42/CON) and CLA (42/CLA) group were slaughtered. The remaining 5 animals of the control (105/CON) and CLA (105/CLA) group were slaughtered after 105 DIM. For financial reasons and the experimental capacity the number of animals was restricted to 5 cows in each group due to the expensive and labor intensive slaughter.

All animals were housed in group pens in a freestall barn equipped with slatted floors and stalls covered with rubber mattresses. The possibility to feed concentrate over a computerized concentrate feeding station existed in each group pen (type RIC; Insentec, B.V., Marknesse, the Netherlands). The diets were formulated to meet the nutritional requirements of dairy cows stated by the German Society of Nutrition Physiology (GfE, 2001). In the prepartum period, all animals were housed together and received a diet consisting of a partial mixed ration (PMR) for ad libitum consumption and $2 \mathrm{~kg}$ concentrate/d in pelleted form by a computerized concentrate feeding station (Table 1).

Table 1. Ingredients and chemical composition of the prepartum diet

\begin{tabular}{lcc}
\hline Variable & Concentrate & $\mathrm{PMR}^{1}$ \\
\hline Ingredient (\%) & & \\
Wheat grain & 25 & \\
Barley grain & 25 & \\
Soybean meal & 20 & \\
Sugar beet pulp, dried & 11 & \\
Zeolithe & 12.5 & \\
Vitamin/mineral premix & 6.5 & \\
Chemical composition & & \\
DM (g/kg) & 894 & 375 \\
Nutrient (g/kg of DM) & & \\
Crude ash & 155 & 86 \\
CP & 173 & 29 \\
Ether extract & 22 & 256 \\
ADF & 68 & 469 \\
NDF & 157 & 11.0 \\
Energy $^{4}$ (MJ/kg of DM) & & 6.7 \\
ME & 10.6 & \\
$\mathrm{NE}_{\mathrm{L}}$ & 6.7 &
\end{tabular}

${ }^{1}$ Partial mixed ration on DM basis (60\% corn silage, $40 \%$ grass silage on DM basis).

${ }^{2}$ According to Grabherr et al. (2009), cows received $250 \mathrm{~g}$ of Zeolithe (IMPAG GmbH, Offenbach, Germany) per day for prevention of hypocalcaemia.

${ }^{3}$ Per kilogram of mineral feed: $105 \mathrm{~g}$ of Na; $80 \mathrm{~g}$ of P; $60 \mathrm{~g}$ of $\mathrm{Ca} ; 50$ $\mathrm{g}$ of $\mathrm{Mg} ; 7 \mathrm{~g}$ of $\mathrm{Zn} ; 5.4 \mathrm{~g}$ of Mn; $1.25 \mathrm{~g}$ of $\mathrm{Cu} ; 100 \mathrm{mg}$ of I; $40 \mathrm{mg}$ of Se; $30 \mathrm{mg}$ of Co; $800,000 \mathrm{IU}$ of vitamin A; 100,000 IU of vitamin $\mathrm{D}_{3}$; $1,500 \mathrm{mg}$ of vitamin $\mathrm{E}$.

${ }^{4}$ Calculation based on nutrient digestibilities measured with wethers (GfE, 1991) and tabulated values (Universität HohenheimDokumentationsstelle, 1997). 
Table 2. Ingredients and chemical composition of the postpartum concentrates and partial mixed ration $\left(\mathrm{PMR}^{1}\right)$

\begin{tabular}{|c|c|c|c|c|}
\hline \multirow[b]{2}{*}{ Variable } & \multicolumn{3}{|c|}{ Concentrate } & \multirow[b]{2}{*}{ PMR } \\
\hline & $\mathrm{CON}$ & CLA & PMR & \\
\hline \multicolumn{5}{|l|}{ Ingredient (\%) } \\
\hline Wheat grain & 39.5 & 39.5 & 41 & \\
\hline Sugar beet pulp, dried & 29 & 29 & 30 & \\
\hline Rapeseed meal & 20 & 20 & 20 & \\
\hline Soybean meal & 6.5 & 6.5 & 6.5 & \\
\hline Vitamin/mineral premix ${ }^{2}$ & 2 & 2 & 2 & \\
\hline Control fat supplement & 2.5 & & & \\
\hline $\mathrm{CLA}^{3}$ supplement & & 2.5 & & \\
\hline Calcium carbonate & 0.5 & 0.5 & 0.5 & \\
\hline \multicolumn{5}{|l|}{ Analyzed chemical profile } \\
\hline $\mathrm{DM}(\mathrm{g} / \mathrm{kg})$ & 873 & 871 & 870 & 445 \\
\hline \multicolumn{5}{|l|}{ Nutrient $(\mathrm{g} / \mathrm{kg}$ of $\mathrm{DM})$} \\
\hline Crude ash & 65 & 69 & 64 & 62 \\
\hline $\mathrm{CP}$ & 182 & 180 & 182 & 124 \\
\hline Ether extract & 50 & 44 & 20 & 28 \\
\hline $\mathrm{ADF}$ & 134 & 133 & 134 & 208 \\
\hline $\mathrm{NDF}$ & 259 & 260 & 265 & 405 \\
\hline \multicolumn{5}{|l|}{ Energy $^{4}(\mathrm{MJ} / \mathrm{kg}$ of $\mathrm{DM})$} \\
\hline $\mathrm{ME}$ & 13.9 & 13.7 & 13.5 & 11.9 \\
\hline $\mathrm{NE}_{\mathrm{L}}$ & 8.9 & 8.7 & 8.7 & 7.5 \\
\hline \multicolumn{5}{|l|}{ CLA $(\mathrm{g} / \mathrm{kg}$ of $\mathrm{DM})$} \\
\hline $\mathrm{C} 18: 2$ trans -10, cis -12 & 0.0 & 1.7 & 0.0 & 0.0 \\
\hline $\mathrm{C} 18: 2$ cis- $9 ;$ trans-11 & 0.0 & 1.6 & 0.0 & 0.0 \\
\hline
\end{tabular}

${ }^{1}$ Partial mixed ration (38\% grass silage, $25 \%$ corn silage, 37\% PMR-concentrate on DM basis).

${ }^{2}$ Per kilogram of mineral feed: $140 \mathrm{~g}$ of Ca; $120 \mathrm{~g}$ of Na; $70 \mathrm{~g}$ of P; $40 \mathrm{~g}$ of Mg; $6 \mathrm{~g}$ of Zn; $5.4 \mathrm{~g}$ of Mn; $1 \mathrm{~g}$ of $\mathrm{Cu} ; 100 \mathrm{mg}$ of I; $40 \mathrm{mg}$ of Se; $5 \mathrm{mg}$ of Co; $1,000,000 \mathrm{IU}$ of vitamin $\mathrm{A} ; 100,000 \mathrm{IU}$ of vitamin $\mathrm{D}_{3} ; 1,500 \mathrm{mg}$ of vitamin E.

${ }^{3}$ Conjugated linoleic acid.

${ }^{4}$ Calculation based on nutrient digestibilities measured with wethers (GfE, 1991).

The 20 animals who received the control or CLA diet after calving were housed in 2 group pens according to the diet. Each pen was equipped with 10 self-feeding stations to provide the PMR (type RIC, Insentec). In addition, all animals were marked with an ear transponder to record the daily individual feed intake at the feeding stations. The diet fed in period 1 and 2, respectively (Table 2), consisted of a PMR composed of $38 \%$ grass silage (35\% Lolium perenne, $32 \%$ Festuca pratensis, $18 \%$ Phleum pratense, $10 \%$ Poa pratensis, and $5 \%$ Festuca rubra), 25\% corn silage (Zea mays), and $37 \%$ concentrate (on a DM basis) and was provided for ad libitum intake.

Additionally, $3.5 \mathrm{~kg}$ of concentrate (on a DM basis), which contained the control fat supplement or the CLA supplement, was provided by the computerized concentrate feeding stations in pelleted form and water was available ad libitum. The cows fed the CLA-supplemented diet obtained $100 \mathrm{~g} / \mathrm{d}$ of a rumen-protected (lipid encapsulation technique) CLA supplement (Lutrell Pure, BASF SE, Ludwigshafen, Germany) and the animals of the control group received $100 \mathrm{~g} / \mathrm{d}$ of a control fat supplement (Silafat, BASF SE). The CLA supplement contained $78 \%$ fatty acids with a propor- tion of approximately $12 \%$ each of the trans-10, cis- 12 CLA isomer and cis-9, trans-11 CLA isomer. The fatty acid profile provided by the CLA supplement and the control fat supplement are shown in Table 3. The pelleted CLA-concentrate contained $1.7 \%$ of the trans-10, cis- 12 CLA isomer and $1.6 \%$ of the cis-9, trans- 11 CLA isomer (Table 2). That implies animals of the CLA group consumed (calculated based on the analyzed proportion in concentrates) $6.0 \mathrm{~g} / \mathrm{d}$ of the trans-10, cis12 CLA-isomer and $5.7 \mathrm{~g} / \mathrm{d}$ of the cis-9, trans- 11 CLA isomer. In the control fat supplement these isomers were substituted by stearic acid.

\section{Measurements and Sample Collection}

In the prepartum period, pooled samples of grass silage, corn silage, and the concentrate were taken over 4 wk. Partial mixed ration samples in the postpartum period were collected 4 times per week directly after feeding from each trough and pooled over approximately 4 wk. Samples of the concentrates were taken once per week and composited monthly. The composition of the PMR was adjusted daily based on changes in DM content of grass and maize silage. In the prepartum 
Table 3. Fatty acid profile of fat supplements ${ }^{1}$

\begin{tabular}{lcc}
\hline $\begin{array}{l}\text { Fatty acid } \\
\text { (\% of total fatty acids) }\end{array}$ & CON & CLA \\
\hline C16:0 & 10.89 & 10.89 \\
C18:0 18 cis-9 & 87.30 & 50.31 \\
CLA & $<0.01$ & 10.66 \\
C18:2 cis-9, trans-11 & & \\
C18:2 trans-10, cis-12 & 0.06 & 11.99 \\
Other CLA & 0.02 & 11.88 \\
Other & 0.15 & 0.95 \\
\hline
\end{tabular}

${ }^{1}$ Supplemental conjugated linoleic acid (CLA) was included in the additional concentrate portion (fed by the computerized concentrate feeding station) as a rumen-protected CLA supplement; for the control $(\mathrm{CON})$ group conjugated linoleic acids were substituted by stearic acid.

period, the daily DMI could not be recorded for technical reasons. In accordance with the different slaughter times (postpartum), in period 1, data are available for 10 animals each in the CLA and CON group. In period 2 , data from 5 animals are available for each treatment. Milking took place twice per day at 0530 and $1530 \mathrm{~h}$. Meanwhile, milk yield was recorded with automatic milk counters and BW was automatically recorded when leaving the milking parlor. Milk samples were taken twice per week and stored at $4^{\circ} \mathrm{C}$ until analysis. From $21 \mathrm{~d}$ prepartum until the slaughter after 42 DIM and immediately before the slaughter after 105 DIM, blood samples were drawn from the vena jugularis once per week after the morning milking. Contemporaneously, BCS was recorded using a 5-point scale (Edmonson et al., 1989). Back fat thickness (BFT) was determined 21 d before expected parturition, at 1 DIM, after 21 DIM, and before slaughter, applying ultrasound (Staufenbiel, 1997). Mastitis was documented and 3 animals of the CON group and 4 of the CLA group were diseased in the first week of lactation. The weak alignment and recovery within a few days of the health complications did not make it necessary to eliminate data from analysis.

The slaughter took place in the slaughter facilities at the experimental station of the Institute of Animal Nutrition, FLI, next to the animals' freestall barn. The slaughter process was carried out in accordance with the methods described by Janssen (2006). After the morning milking, the cow was transported to the slaughter facilities, weighed, stunned with a captive bolt gun, and exsanguinated. Blood was collected and weighed. Body parts were weighed as they were dissected from the animal. The head, udder, tail, and feet (below carpal joint or hock) were detached first. Claws were sawed off, weighed and removed. The full gastrointestinal tract, urinary, and gall bladder were removed. The hide, heart, lung, liver, kidneys, uterus, spleen, thyroid gland, thymus, and retroperitoneal adipose depot were dissected and weighed during the slaughter process. After separation of the gastrointestinal tract into reticulo-rumen, omasum/ abomasum, and intestine, these parts were weighed full and after opening and cleaning of ingesta. Adherent mesenteric fat at the intestine and the omental adipose depot, which included fat from the reticulo-rumen, omasum, and abomasum, were cut off and weighed. The gastrointestinal tract fill was calculated as the difference in weights of the full and cleaned gastrointestinal tract. The carcass was divided longitudinally into 2 symmetric parts, weighed, and stored at $4^{\circ} \mathrm{C}$. The next day, carcass parts were weighed once again to determine water loss, and s.c. adipose tissue was dissected manually from the left carcass with a knife and weighed. The whole s.c. adipose depot weight was calculated by multiplying the weight of the s.c. adipose tissue of the left carcass with the quotient resulting from the weight of both carcass parts and the weight of the left carcass. The empty body weight (EBW) is defined as the whole body of the cow without claws off cut, ingesta, and content of urinary and gall bladder. It was calculated as the sum of all body part weights, which were recorded during the slaughter process.

\section{Analyses}

The composition of the feedstuffs (DM, crude ash, $\mathrm{CP}$, ether extract, NDF, and ADF) was determined according to the suggestions of the Association of German Agricultural Analysis and Research Centres (VDLUFA, 1993). The fatty acid profile of fat supplements and feedstuffs was analyzed by extracting the lipid content according to Folch et al. (1957). The lipid extract was incubated with Boron trifluoride $\left(\mathrm{BF}_{3}\right)$ to produce fatty acid methyl esters (FAME), which were purified by thin-layer chromatography (SIL G-25 UV $\mathrm{UV}_{254}$, Machinery-Nagel, Germany) and quantified by GC (GC-17A Version 3, Shimadzu Corp., Kyoto, Japan) equipped with an autosampler and flame ionization detector. The applied GC procedures were as described previously by Flachowsky et al. (2006).

Milk samples were analyzed for fat, protein, lactose, and urea concentration, and SCC using an infrared milk analyzer (Milkoscan FT 6000 combined with a Fossomatic 5000; Foss Electric, Hillerød, Denmark).

Blood samples were analyzed for plasma concentrations of glucose, NEFA, and BHBA by enzymatic analysis. For glucose, a commercial kit (Glucose Hexokinase Fluid 5+1; MTI Diagnostics, Idstein, Germany), containing the enzyme glucose hexokinase, was used. Nonesterified fatty acids and BHBA were analyzed with commercial kits (NEFA C; Wako Chemicals GmbH, 


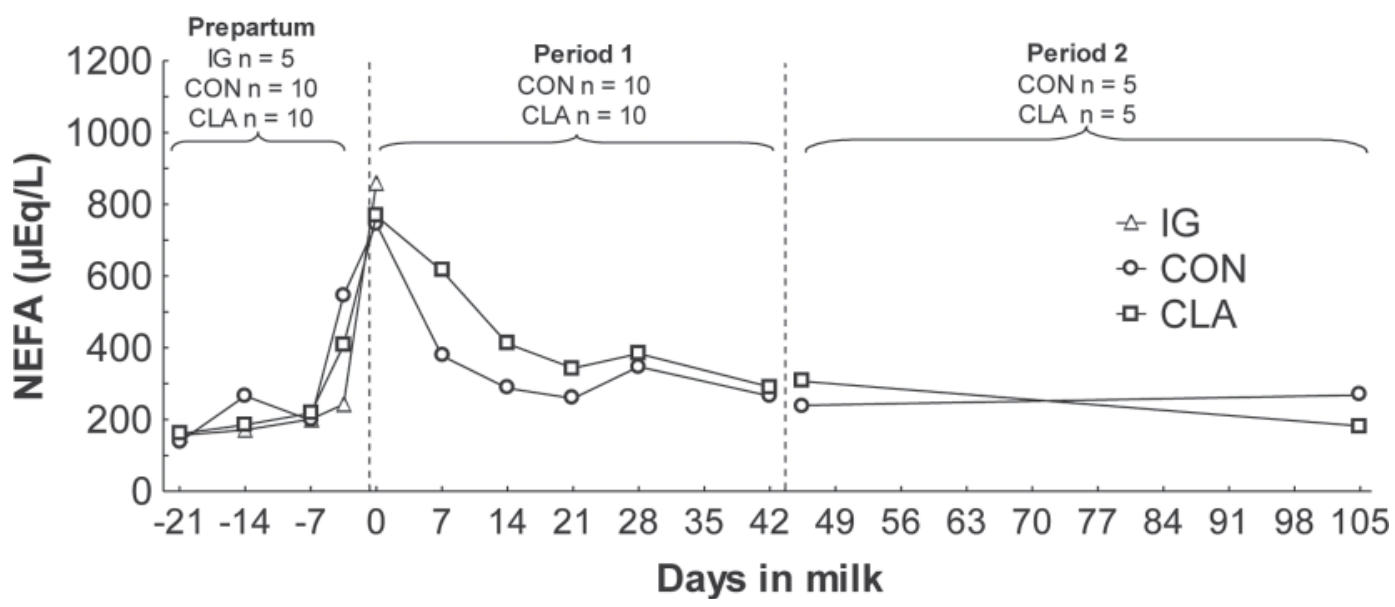

Figure 1. Development of NEFA plasma concentrations (means) during the trial. Prepartum, all animals received the same diet and the curve for the initial group (IG) ended after parturition due to slaughter. Groups did not differ in this period $(P=0.279)$ and the standard error of the means averaged 21 and ranged from 9 to $23 \mu \mathrm{Eq} / \mathrm{L}$. In period 1, each group consisted of 10 animals and in period 2 , consisted of 5 animals available in each group, because of the slaughter after 42 DIM. Cows received from 1 DIM until slaughter $100 \mathrm{~g} / \mathrm{d}$ of a control fat supplement $(\mathrm{CON})$ or $100 \mathrm{~g} / \mathrm{d}$ of a conjugated linoleic acid supplement (CLA). Animals of the CLA group consumed $6 \mathrm{~g} / \mathrm{d}$ of trans-10, cis-12 CLA and 6 $\mathrm{g} / \mathrm{d}$ cis-9, trans-11 CLA. In period 1 , no differences between the groups were observed $(P=0.171)$ and the standard error of the means averaged 53 and ranged from 39 to $90 \mu \mathrm{Eq} / \mathrm{L}$. In period 2, no differences between the groups were observed $(P=0.871)$ and the standard error of the means averaged 41 and ranged from 40 to $43 \mu \mathrm{Eq} / \mathrm{L}$.

Neuss and Ranbut, Randox Laboratories GmbH, Wülfrath, Germany).

\section{Calculations}

Based on the equations published by the German Society of Nutrition Physiology (GfE, 2001), the $\mathrm{NE}_{\mathrm{M}}$ and $\mathrm{NE}_{\mathrm{L}}$, as well as milk energy concentration and output, were calculated as follows:

$$
\mathrm{NE}_{\mathrm{M}}\left(\mathrm{MJ} \text { of } \mathrm{NE}_{\mathrm{L}} / \mathrm{d}\right)=0.293 \times \mathrm{BW}^{0.75},
$$

Milk energy concentration $\left(\mathrm{MJ}\right.$ of $\left.\mathrm{NE}_{\mathrm{L}} / \mathrm{kg}\right)=0.38$

$\times$ milk fat $(\%)+0.21 \times$ milk protein $(\%)+0.95$,

$\mathrm{NE}_{\mathrm{L}}\left(\mathrm{MJ}\right.$ of $\left.\mathrm{NE}_{\mathrm{L}} / \mathrm{d}\right)=$ [milk energy concentration

$$
\left.\left(\mathrm{MJ} \text { of } \mathrm{NE}_{\mathrm{L}} / \mathrm{kg}\right)+0.086\right] \times \text { milk yield }(\mathrm{kg} / \mathrm{d}) \text {. }
$$

Fat-corrected milk was calculated based on the equation of Gaines (1928):

$$
\begin{gathered}
\text { FCM }(\mathrm{kg} / \mathrm{d})=\{[\text { milk fat }(\%) \times 0.15]+0.4\} \\
\times \text { daily milk yield }(\mathrm{kg} / \mathrm{d}) .
\end{gathered}
$$

The net energy balance was calculated with the following equation:
Net energy balance $\left(\mathrm{MJ}\right.$ of $\left.\mathrm{NE}_{\mathrm{L}} / \mathrm{d}\right)=$ energy intake

$$
\begin{gathered}
\left(\mathrm{MJ} \text { of } \mathrm{NE}_{\mathrm{L}} / \mathrm{d}\right)-\left[\mathrm{NE}_{\mathrm{M}}\left(\mathrm{MJ} \text { of } \mathrm{NE}_{\mathrm{L}} / \mathrm{d}\right)\right. \\
\left.+\mathrm{NE}_{\mathrm{L}}\left(\mathrm{MJ} \text { of } \mathrm{NE}_{\mathrm{L}} / \mathrm{d}\right)\right] .
\end{gathered}
$$

The milk energy concentration (MJ of $\mathrm{NE}_{\mathrm{L}} / \mathrm{kg}$ ) multiplied by daily milk yield $(\mathrm{kg} / \mathrm{d})$ results in daily milk energy output (MJ of $\mathrm{NE}_{\mathrm{L}} / \mathrm{d}$ ). Energy intake was calculated by multiplying the daily DMI with the overall energy content of the PMR and the concentrate. The liver and adipose tissue weights were referred to EBW and additionally presented as proportion of EBW (in percent) for consideration of different EBW of the animals.

\section{Statistical Analyses}

All statistical analyses were carried out using the software SAS version 9.1 (SAS Institute, 2004). Data for DMI, milk yield, BW, and milk components recorded during the 2 periods of the trial were reduced to weekly means. These variables, plus data for BCS, BFT, NEFA, glucose, and BHBA were analyzed as repeated measures using the MIXED procedure of SAS. An autoregressive covariance structure was modeled using week of lactation as the repeated effect. The model contained treatment, week of lactation, and interactions of treatment $\times$ week of lactation as the fixed effects. Cows were treated as random effect. Weights of empty 
body, liver, and adipose depots were analyzed using the GLM procedure of SAS. The CLA and CON groups at the 42 and 105 DIM slaughter were compared with the IG with the Dunnett test. For all analyses, significance was declared when $P$-values were $<0.05$ and a tendency was noted when $0.05<P<0.10$.

\section{RESULTS}

The initial BW recorded $21 \mathrm{~d}$ before parturition was $583 \mathrm{~kg}( \pm 6)$ for the IG, $571 \mathrm{~kg}( \pm 13)$ for the $42 / \mathrm{CON}$ group, $577 \mathrm{~kg}( \pm 27)$ for the $42 / \mathrm{CLA}$ group, $589 \mathrm{~kg}$ $( \pm 12)$ for the $105 / \mathrm{CON}$ group, and $573 \mathrm{~kg}( \pm 22)$ for the 105/CLA group. The values for BCS, BFT, BHBA, and glucose concentration were similar between the groups in the prepartum period. The NEFA concentration in blood plasma showed no differences in the prepartum period between the groups (Figure 1).

In period 1, milk fat content was $14.1 \%$ lower for cows receiving CLA (Table 4). Milk fat content was decreased first after 28 DIM and reached a plateau after 49 DIM (Figure 2A). Milk fat yield and milk protein yield were not affected by CLA supplementation in period 1. Conditional to the mastitis occurrence, the SCC tended to be higher in period 1 in the CLA group
(Table 4). In period 2, CLA supplementation decreased milk fat content $(25.4 \%)$, milk fat yield $(17.1 \%)$, and milk protein content (10.4\%; Table 5). Overall, the milk protein yield was unchanged. In both periods, the milk lactose content and yield were similar. Milk energy concentration was lower in periods 1 and 2 for the CLA group; however milk energy output was equal for the CLA and CON group. Milk yield was not affected by CLA supplementation. The DMI between CON and CLA groups did not differ in period 1 but tended to be decreased in period 2 by CLA feeding (Table 4 and $5)$. The calculated energy balance was negative until 14 DIM (Figure 3B). Differences between CLA-treated animals and controls were not observed in period 1 , although a trend for a decreased energy balance in period 2 was seen (Table 5 ).

In periods 1 and $2, \mathrm{BW}$ and BCS were not changed by CLA supplementation, although BFT showed a decrease in period 2 in the CLA group. Overall, plasma NEFA (Figure 1), BHBA, and glucose concentrations were not affected in any period of the trial (Table 4 and $5)$. Performance and energy variables during period 1 were similar for the $42 / \mathrm{CON}$ compared with the 105/ CON and the 42/CLA compared with the 105/CLA group.

Table 4. Performance, milk composition, and energy variables (LSM) during period 1 (1 until 42 DIM)

\begin{tabular}{|c|c|c|c|c|c|}
\hline \multirow[b]{2}{*}{ Variable } & \multicolumn{2}{|c|}{ Treatment $^{1}$} & \multirow[b]{2}{*}{ SEM } & \multicolumn{2}{|c|}{$P$-value } \\
\hline & $\mathrm{CON}$ & CLA & & Trt & $\operatorname{Trt} \times \mathrm{WL}^{2}$ \\
\hline BW (kg) & 497.7 & 487.6 & 12.5 & 0.576 & 0.386 \\
\hline DMI $(\mathrm{kg} / \mathrm{d})$ & 14.8 & 14.1 & 0.4 & 0.233 & 0.520 \\
\hline Net energy intake (MJ of $\mathrm{NE}_{\mathrm{L}} / \mathrm{d}$ ) & 112.1 & 106.7 & 3.5 & 0.281 & 0.741 \\
\hline Milk yield $(\mathrm{kg} / \mathrm{d})$ & 23.4 & 24.5 & 0.9 & 0.396 & 0.801 \\
\hline FCM $(\mathrm{kg} / \mathrm{d})$ & 24.6 & 23.7 & 1.0 & 0.545 & 0.404 \\
\hline \multicolumn{6}{|l|}{ Milk fat } \\
\hline Content (\%) & $4.40^{\mathrm{a}}$ & $3.78^{\mathrm{b}}$ & 0.15 & 0.010 & 0.214 \\
\hline Yield (kg/d) & 1.02 & 0.92 & 0.05 & 0.164 & 0.057 \\
\hline \multicolumn{6}{|l|}{ Milk protein } \\
\hline Content (\%) & 3.42 & 3.32 & 0.05 & 0.198 & 0.081 \\
\hline Yield (kg/d) & 0.79 & 0.80 & 0.02 & 0.816 & 0.423 \\
\hline \multicolumn{6}{|l|}{ Milk lactose } \\
\hline Content (\%) & 4.88 & 4.87 & 0.03 & 0.771 & 0.178 \\
\hline Yield $(\mathrm{kg} / \mathrm{d})$ & 1.14 & 1.20 & 0.04 & 0.379 & 0.701 \\
\hline Milk urea $(\mathrm{mg} / \mathrm{kg})$ & $139^{\mathrm{a}}$ & $113^{\mathrm{b}}$ & 4 & $<0.001$ & 0.195 \\
\hline $\mathrm{SCC} \times 1,000 / \mathrm{mL}$ & 254 & 553 & 113 & 0.082 & 0.121 \\
\hline \multicolumn{6}{|l|}{ Energy variable } \\
\hline Milk energy concentration $(\mathrm{MJ} / \mathrm{kg})$ & $3.34^{\mathrm{a}}$ & $3.08^{\mathrm{b}}$ & 0.06 & 0.007 & 0.156 \\
\hline Milk energy output (MJ/d) & 77.7 & 74.9 & 3.1 & 0.523 & 0.184 \\
\hline Net energy balance (MJ of $\mathrm{NE}_{\mathrm{L}} / \mathrm{d}$ ) & 1.8 & -0.7 & 3.6 & 0.623 & 0.646 \\
\hline $\mathrm{BCS}$ & 3.0 & 3.0 & 0.03 & 0.865 & 0.521 \\
\hline $\mathrm{BFT}^{3}(\mathrm{~cm})$ & 2.5 & 2.6 & 0.07 & 0.921 & 0.520 \\
\hline $\mathrm{BHBA}(\mathrm{mmol} / \mathrm{L})$ & 0.54 & 0.58 & 0.04 & 0.460 & 0.609 \\
\hline Glucose (mmol/L) & 3.76 & 3.65 & 0.06 & 0.194 & 0.282 \\
\hline \multicolumn{6}{|c|}{$\overline{\mathrm{a}, \mathrm{b}}$ Least squares means within a row with different superscripts differ $(P<0.05)$. } \\
\hline \multicolumn{6}{|c|}{$\begin{array}{l}{ }^{1} \text { Treatment (Trt): cows of the conjugated linoleic acid (CLA) group }(\mathrm{n}=10) \text { consumed } 6 \mathrm{~g} / \mathrm{d} \text { each of } \operatorname{trans}-10 \\
\text { cis- } 12 \text { CLA and cis-9, trans-11 CLA. Cows of the control (CON) group }(\mathrm{n}=10) \text { received a control fat supple- } \\
\text { ment, in which the CLA were substituted with stearic acid. }\end{array}$} \\
\hline
\end{tabular}



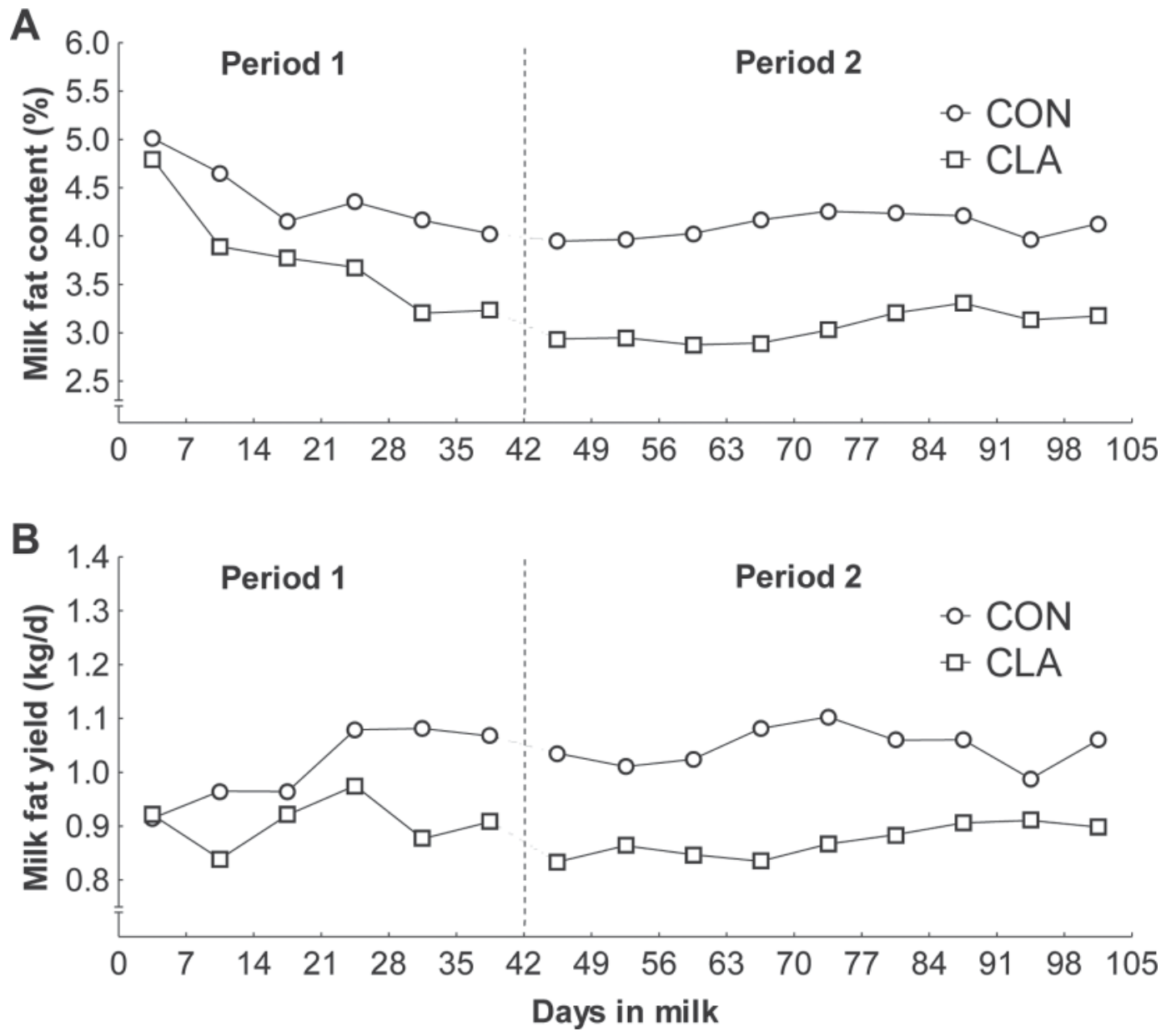

Figure 2. Development of milk fat content (A) and milk fat yield (B) during the 2 periods of the trial. Cows received $100 \mathrm{~g} / \mathrm{d}$ of a control fat supplement (CON) or $100 \mathrm{~g} / \mathrm{d}$ of a conjugated linoleic acid supplement (CLA). Animals of the CLA group consumed $6 \mathrm{~g} / \mathrm{d}$ of trans-10, cis-12 CLA and $6 \mathrm{~g} / \mathrm{d}$ of cis-9, trans-11 CLA. In period 1 each group consisted of 10 animals and in period 2 , of 5 animals, because of the slaughter after 42 DIM. Values represent weekly means. The weekly standard error of the means for milk fat content averaged 0.18 and ranged from 0.11 to $0.42 \%$ in period 1 and averaged 0.24 and ranged from 0.21 to $0.28 \%$ in period 2 . The weekly standard error of the means for milk fat yield averaged 0.05 and ranged from 0.03 to $0.07 \mathrm{~kg} / \mathrm{d}$ in period 1 and averaged 0.05 and ranged from 0.03 to $0.06 \mathrm{~kg} / \mathrm{d}$ in period 2 .

Compared with the EBW of the IG, the EBW was not influenced by CLA supplementation. The liver weight and the liver weight as a proportion of EBW was lower in the IG compared with all other groups (Table 6). The retroperitoneal adipose depot reacted most sensitively to lactation progression. Its weight and the weight as a proportion of EBW was decreased for the $42 / \mathrm{CON}$, $105 / \mathrm{CON}$, and 105/CLA groups compared with the IG, whereas the 42/CLA group tended to be decreased. For the omental, mesenteric, and s.c. adipose depot, no differences with regard to CLA supplementation were found (Table 6).

\section{DISCUSSION}

In the present investigation, the decrease in milk fat content and yield was consistent with results from other studies using similar trans-10 cis-12 CLA doses in the range of 3.4 to $9 \mathrm{~g} / \mathrm{d}$ during early or established lactation (Perfield et al., 2002; Castañeda-Gutiérrez et al., 2005; Brömmel et al., 2007; Odens et al., 2007). The animals in this trial consumed $6 \mathrm{~g} / \mathrm{d}$ trans-10, cis-12 CLA. In a study by Castañeda-Gutiérrez et al. (2007), it was calculated, based on equations of de Veth et al. (2004), that $18 \%$ of the trans-10, cis-12 CLA escaped from rumen biohydrogenation. Assuming the same conditions in our trial, the implemented dose provided 1.1 $\mathrm{g}$ of trans-10, cis-12 CLA at the duodenum. This dose could lead to a decrease in milk fat yield of approximately $12 \%$ (de Veth et al., 2004). In periods 1 and 2 of the current study, we observed a decrease in milk fat yield of 10 and $17 \%$ for CLA-treated animals, respectively. Furthermore, a lack of decrease in milk fat until 28 DIM occurred and is responsible for an unchanged milk fat yield in period 1. This gradual response of 
VON SOOSTEN ET AL.

Table 5. Performance, milk composition, and energy variables (LSM) during period 2 (>42 until 105 DIM)

\begin{tabular}{|c|c|c|c|c|c|}
\hline \multirow[b]{2}{*}{ Variable } & \multicolumn{2}{|c|}{ Treatment $^{1}$} & \multirow[b]{2}{*}{ SEM } & \multicolumn{2}{|c|}{$P$-value } \\
\hline & $\mathrm{CON}$ & CLA & & Trt & $\operatorname{Trt} \times \mathrm{WL}^{2}$ \\
\hline BW (kg) & 524.5 & 491.3 & 19.8 & 0.268 & 0.958 \\
\hline DMI $(\mathrm{kg} / \mathrm{d})$ & 18.1 & 16.6 & 0.6 & 0.075 & 0.034 \\
\hline Net energy intake (MJ of $\left.\mathrm{NE}_{\mathrm{L}} / \mathrm{d}\right)$ & 137.6 & 126.8 & 4.2 & 0.094 & 0.176 \\
\hline Milk yield $(\mathrm{kg} / \mathrm{d})$ & 25.9 & 28.6 & 1.3 & 0.176 & 0.428 \\
\hline $\mathrm{FCM}(\mathrm{kg} / \mathrm{d})$ & 26.2 & 24.5 & 0.7 & 0.118 & 0.825 \\
\hline \multicolumn{6}{|l|}{ Milk fat } \\
\hline Content $(\%)$ & $4.10^{\mathrm{a}}$ & $3.06^{\mathrm{b}}$ & 0.16 & 0.001 & 0.993 \\
\hline Yield $(\mathrm{kg} / \mathrm{d})$ & $1.05^{\mathrm{a}}$ & $0.87^{\mathrm{b}}$ & 0.03 & 0.001 & 0.858 \\
\hline \multicolumn{6}{|l|}{ Milk protein } \\
\hline Content $(\%)$ & $3.35^{\mathrm{a}}$ & $3.00^{\mathrm{b}}$ & 0.09 & 0.025 & 0.058 \\
\hline Yield $(\mathrm{kg} / \mathrm{d})$ & 0.86 & 0.86 & 0.03 & 0.981 & 0.289 \\
\hline \multicolumn{6}{|l|}{ Milk lactose } \\
\hline Content (\%) & 4.90 & 4.85 & 0.02 & 0.110 & 0.760 \\
\hline Yield (kg/d) & 1.27 & 1.39 & 0.06 & 0.199 & 0.275 \\
\hline Milk urea $(\mathrm{mg} / \mathrm{kg})$ & $145^{\mathrm{a}}$ & $95^{\mathrm{b}}$ & 8 & $<0.001$ & 0.426 \\
\hline $\mathrm{SCC} \times 1,000 / \mathrm{mL}$ & 34 & 275 & 101 & 0.108 & 0.564 \\
\hline \multicolumn{6}{|l|}{ Energy variable } \\
\hline Milk energy concentration $(\mathrm{MJ} / \mathrm{kg})$ & $3.21^{\mathrm{a}}$ & $2.74^{\mathrm{b}}$ & 0.08 & 0.002 & 0.996 \\
\hline Milk energy output $(\mathrm{MJ} / \mathrm{d})$ & 82.4 & 78.3 & 2.5 & 0.264 & 0.694 \\
\hline Net energy balance $\left(\mathrm{MJ}\right.$ of $\left.\mathrm{NE}_{\mathrm{L}} / \mathrm{d}\right)$ & 20.9 & 15.4 & 2.1 & 0.082 & 0.710 \\
\hline $\mathrm{BCS}$ & 3.0 & 2.9 & 0.06 & 0.105 & 0.478 \\
\hline $\mathrm{BFT}^{3}(\mathrm{~cm})$ & $2.63^{\mathrm{a}}$ & $2.32^{\mathrm{b}}$ & 0.08 & 0.021 & 0.777 \\
\hline $\operatorname{BHBA}(\mathrm{mmol} / \mathrm{L})$ & 0.59 & 0.57 & 0.05 & 0.857 & 0.868 \\
\hline Glucose $(\mathrm{mmol} / \mathrm{L})$ & 3.80 & 3.78 & 0.09 & 0.902 & 0.068 \\
\hline
\end{tabular}

milk fat yield to CLA is also reported in other studies (Perfield et al., 2002; Bernal-Santos et al., 2003; Moore et al., 2004; Castañeda-Gutiérrez et al., 2005; MetzgerPetersen et al., 2008; Sigl et al., 2010). Open to question is, if the start of CLA supplementation before calving could be a reason for this observation. However, a start of supplementation 2 wk before expected parturition showed the same lack of response (Castañeda-Gutiérrez et al., 2005; Metzger-Petersen et al., 2008).

A decrease in milk protein content in period 2 was observed, whereas milk protein yield was unaffected for CLA-treated animals in the present study. This could be explained as an effect of diluting. The equal milk protein yield in both periods is dispensed on a numerically higher level of milk yield (Figure 3A). Additionally, the decreased milk urea content in the CLA group in both periods pointed to a protein deficit, which is potentially caused by the trend for a decreased DMI in the CLA group and maybe fortified the decrease in milk protein content. Similar results for decreased DMI and milk protein content for CLA-treated cows, but no change in milk protein yield, were reported by Moallem et al. (2010). Moreover, several studies observed no effect of CLA on milk protein content and yield (Bernal-Santos et al., 2003; Moore et al., 2004; Perfield et al., 2004; Castañeda-Gutiérrez et al., 2005). For DMI, a recent study showed a decrease for CLA-fed cows (Pappritz et al., 2011); concededly, reasons for this effect are not known. In several other trials, DMI was not influenced by CLA administration, no matter whether abomasally infused or mixed into the feed (Bernal-Santos et al., 2003; Shingfield et al., 2004; Odens et al., 2007; Liermann and Schwarz, 2007; Liermann et al., 2008; Harvatine et al., 2009). However, in a review, Bauman et al. (2008) mentioned that in periods of inadequate energy intake, CLA-induced MFD coincides with marginal, not statistically detectable, changes in DMI.

In the present study, the trend for a decreased DMI for the CLA group in period 2 contributed to a lower energy balance. Interactions of treatment and week of lactation in period 2 occurred for DMI (Table 4), but the reasons for this interaction are unclear. The effect of DMI, in combination with a moderate increase in milk yield of $4.7 \%$ in period 1 and $10.4 \%$ in period 2 (Figure 2A), lead to no positive CLA effects on the calculated energy balance. The lack of MFD response in period 1 and the moderate increase in milk yield with continuous CLA feeding during both periods (Figure 


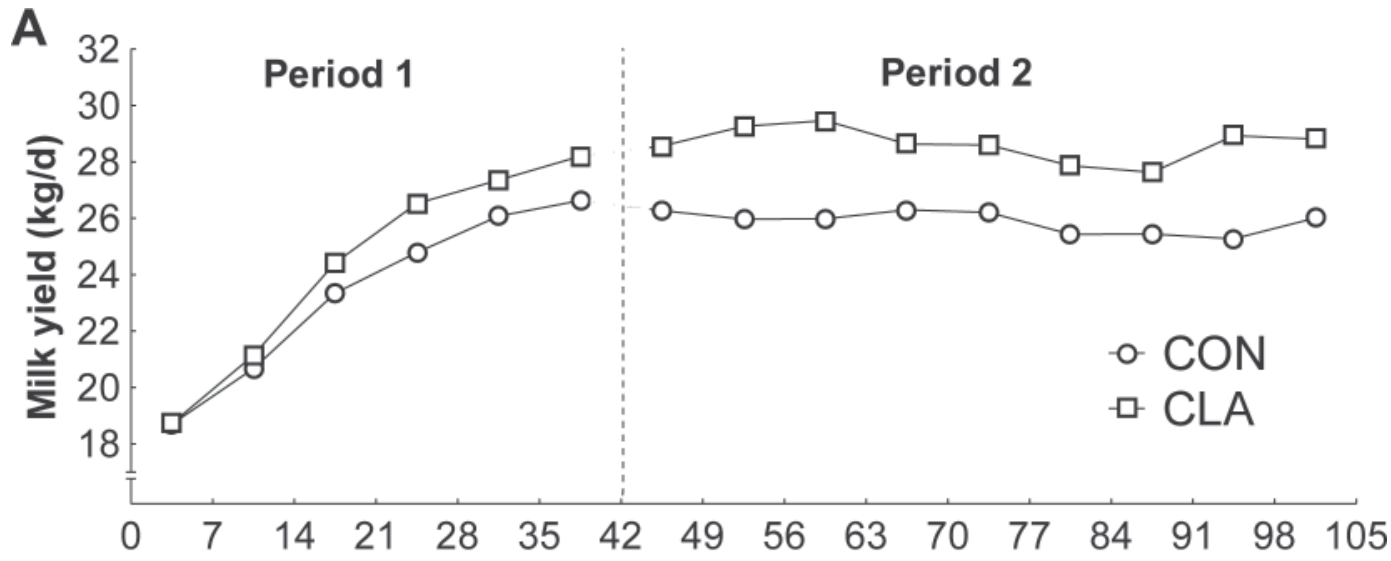

B

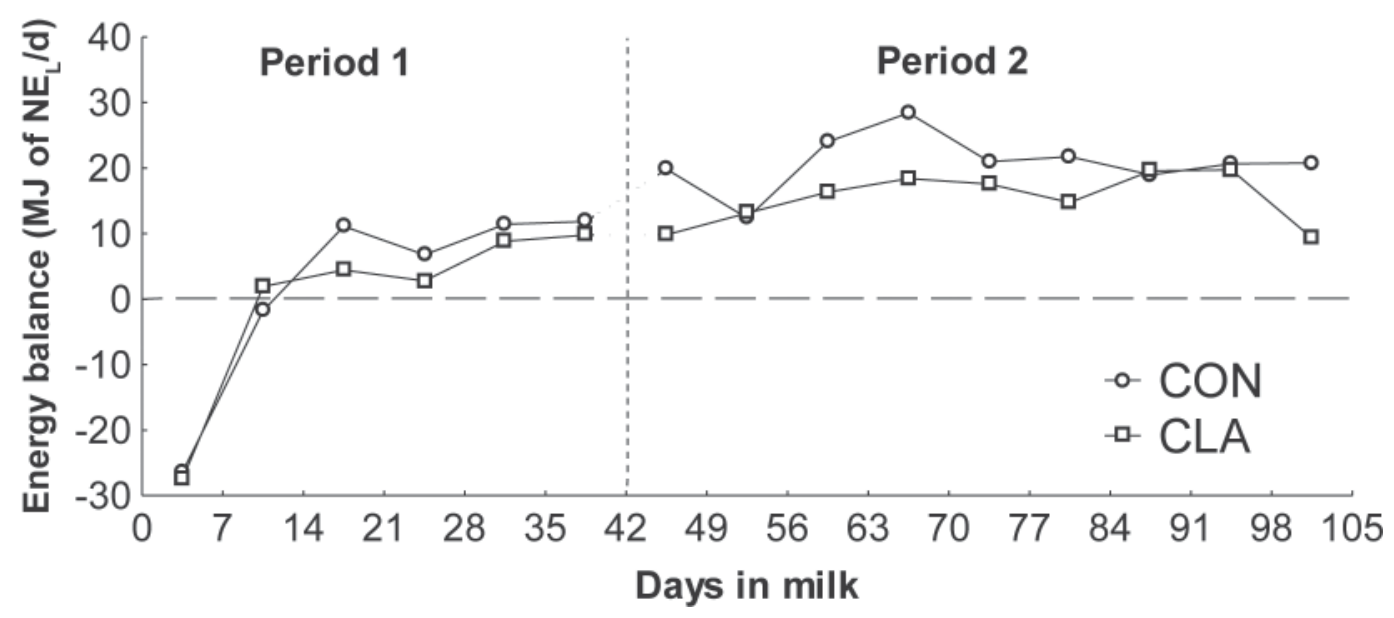

Figure 3. Development of milk yield (A) and energy balance (B) during the 2 periods of the trial. Cows received $100 \mathrm{~g} / \mathrm{d}$ of a control fat supplement $(\mathrm{CON})$ or $100 \mathrm{~g} / \mathrm{d}$ of a conjugated linoleic acid supplement (CLA). Animals of the CLA group consumed $6 \mathrm{~g} / \mathrm{d}$ of trans-10, cis-12 CLA and $6 \mathrm{~g} / \mathrm{d}$ cis-9, trans-11 CLA. In period 1, each group consisted of 10 animals and in period 2, of 5 animals, because of the slaughter after 42 DIM. Values represent weekly means. The weekly standard error of the means for milk vield averaged 0.75 and ranged from 0.71 to $0.85 \mathrm{~kg} / \mathrm{d}$ in period 1 and averaged 1.14 and ranged from 0.84 to $1.28 \mathrm{~kg} / \mathrm{d}$ in period 2 . The weekly standard error of the means for net energy balance averaged 3.55 and ranged from 2.47 to $5.68 \mathrm{MJ}$ of $\mathrm{NE}_{\mathrm{L}} / \mathrm{d}$ in period 1 and averaged 3.28 and ranged from 2.31 to $5.19 \mathrm{MJ}$ of $\mathrm{NE} / \mathrm{d}$ in period 2 .

$3 \mathrm{~A})$ are responsible for an unchanged milk energy output despite a decreased milk energy concentration in both periods. These results indicate that energy spared by CLA-induced MFD is repartitioned to an increased milk yield and explain why the calculated energy balance was not improved in this trial. The obvious, but not statistically detectable, CLA-induced milk yield response during period 1 and 2 (Figure 2A) could lead back to the moderate slope of milk yield in period 1 and the low animal number in period 2. Bernal-Santos et al. (2003) observed similar circumstances in early lactation and reasoned a milk yield response by CLA administration during periods of inadequate energy intake. In our study, only primiparous cows were used and energy supply was balanced after 14 DIM, whereby the increasing milk yield became obvious after 21 DIM (Figure $3 \mathrm{~A}$ ). This is in contrast to the duration of nega- tive energy balance in pluriparous cows (Bauman and Currie, 1980) or a trial with primi- and pluriparous cows (Pappritz et al., 2011) in which the negative energy balance lasted until wk 8 to 12 of lactation. With regard to multiparous cows, it is questionable if the milk yield response only occurred in times of negative energy balance, because milk yield response continued until the end of the present trial and energy was still repartitioned to milk yield despite a positive calculated energy balance.

Milk yield, and consequentially, the energy demand, in primiparous cows range in a smaller magnitude than in pluriparous cows. Nevertheless, mobilization of body reserves is still needed to cover energy requirements. Moreover, growth is not completed and requires additional energy (Coffey et al., 2006). Neither alleviation nor a reinforcement of mobilization of body reserves 
Table 6. Empty body weight (EBW), liver weight, and adipose depot weights and the proportion of liver weight and adipose depot weights of EBW (means)

\begin{tabular}{|c|c|c|c|c|c|c|}
\hline \multirow[b]{2}{*}{ Variable } & \multicolumn{5}{|c|}{ Treatment $^{1}$} & \multirow[b]{2}{*}{$\mathrm{SEM}^{2}$} \\
\hline & $\begin{array}{c}\mathrm{IG} \\
(\mathrm{n}=5)\end{array}$ & $\begin{array}{c}42 / \mathrm{CON} \\
(\mathrm{n}=5)\end{array}$ & $\begin{array}{c}\text { 42/CLA } \\
(\mathrm{n}=5)\end{array}$ & $\begin{array}{c}105 / \mathrm{CON} \\
(\mathrm{n}=5)\end{array}$ & $\begin{array}{c}\text { 105/CLA } \\
(\mathrm{n}=5)\end{array}$ & \\
\hline EBW (kg) & 447 & 397 & 402 & 434 & 413 & 15 \\
\hline \multicolumn{7}{|l|}{ Liver } \\
\hline Weight $(\mathrm{kg})$ & 6.58 & $8.06^{*}$ & $8.14^{*}$ & $9.34^{* * *}$ & $9.16^{* * *}$ & 0.39 \\
\hline Proportion of EBW (\%) & 1.48 & $2.04^{* * *}$ & $2.02 * * *$ & $2.16^{* * *}$ & $2.22^{* * *}$ & 0.09 \\
\hline \multicolumn{7}{|l|}{ Adipose $\operatorname{depot}^{3}$} \\
\hline Weight $(\mathrm{kg})$ & 30.03 & 20.42 & 25.62 & 22.29 & 19.12 & 3.03 \\
\hline Proportion of EBW (\%) & 6.69 & 5.13 & 6.29 & 5.08 & 4.56 & 0.58 \\
\hline \multicolumn{7}{|l|}{ Retroperitoneal } \\
\hline Weight $(\mathrm{kg})$ & 8.76 & $4.58^{*}$ & $5.78 \dagger$ & $5.56^{*}$ & $4.27^{* *}$ & 0.97 \\
\hline Proportion of EBW (\%) & 1.95 & $1.14^{*}$ & $1.42 \dagger$ & $1.26^{*}$ & $1.00^{* *}$ & 0.19 \\
\hline \multicolumn{7}{|l|}{ Omental } \\
\hline Weight $(\mathrm{kg})$ & 11.02 & 7.58 & 9.11 & 8.53 & 7.40 & 1.14 \\
\hline Proportion of EBW (\%) & 2.45 & 1.91 & 2.24 & 1.94 & 1.76 & 0.22 \\
\hline \multicolumn{7}{|l|}{ Mesenteric } \\
\hline Weight $(\mathrm{kg})$ & 5.93 & 4.97 & 5.87 & 4.44 & 4.48 & 0.54 \\
\hline Proportion of EBW (\%) & 1.33 & 1.24 & 1.44 & 1.02 & 1.08 & 0.11 \\
\hline \multicolumn{7}{|l|}{ s.c. depot } \\
\hline Weight $(\mathrm{kg})$ & 4.32 & 3.29 & 4.86 & 3.75 & 2.98 & 0.66 \\
\hline Proportion of EBW (\%) & 0.97 & 0.83 & 1.19 & 0.86 & 0.71 & 0.14 \\
\hline
\end{tabular}

${ }^{1}$ Treatment: cows of the initial group (IG) received no fat supplement and no conjugated linoleic acid (CLA). Cows of the CLA groups consumed $6 \mathrm{~g} / \mathrm{d}$ each of trans-10, cis-12 CLA and cis-9, trans-11 CLA. Cows of the control (CON) groups received a control fat supplement, in which the CLA were substituted with stearic acid.

${ }^{2}$ Pooled SEM.

${ }^{3}$ Sum of the retroperitoneal, omental, mesenteric, and s.c. adipose depots.

$\dagger$ Indicates means tended to be significantly different $(P<0.10)$ from those of the IG (Dunnett test).

*Indicates means are significantly different $(P<0.05)$ from those of the IG (Dunnett test).

**Indicates means are highly significantly different $(P<0.01)$ from those of the IG (Dunnett test).

***Indicates means are very highly significantly different $(P<0.001)$ from those of the IG (Dunnett test).

induced by CLA supplementation is detectable by the measured BW and BCS in the current trial; however, BFT was decreased in period 2 for the CLA group. Similar energy balances and no differences in plasma NEFA concentrations between the CLA and the CON group were consistent with the development of $\mathrm{BW}$ and BCS in both groups. This is in line with other trials, which observed no differences in BW and BCS (BernalSantos et al., 2003; Moore et al., 2004; CastañedaGutiérrez et al., 2005, 2007). However, in the study of Odens et al. (2007), CLA-supplementation diminishes the BW and BCS loss with an improved energy balance at the same time.

In contrast to BW, the EBW is a more appropriate variable to illustrate the mobilization of body reserves, because the ingesta part of BW increases with progressive lactation, conditional to the increase in DMI in early lactation (Flachowsky et al., 2004). The decrease of EBW at the 42 DIM slaughter time is obvious, but not significant, in both groups compared with the IG, and conforms with results for BCS and BFT in period 1. This suggests no influence of CLA on the mobilization of body reserves and no effects on body condition. The animals slaughtered after 105 DIM showed small increases in EBW, with regard to the 42 DIM slaughter time, and indicate that mobilization of body reserves occurs mainly during the first 42 DIM.

The development of increased plasma NEFA concentrations indicate that the highest mobilization of body tissue occurred within $7 \mathrm{~d}$ before parturition up to 21 DIM (Figure 1). This is concurrent with the cessation of a negative energy balance in the present trial, but no differences were found between the CLA and control treatment. A trial by Sigl et al. (2010) with primiparous cows and other studies (Bernal-Santos et al., 2003; Moore et al., 2004; Castañeda-Gutiérrez et al., 2005) also showed no effect of CLA supplementation on plasma NEFA concentrations.

The mobilization of body reserves increased plasma NEFA concentrations and this resulted in an increased fatty acid accumulation in the liver (Grummer, 1993). Dramatic decreases of adipose depots in mice were paralleled by a marked hepatomegalia (TsuboyamaKasaoka et al., 2000; Clément et al., 2002; Jaudszus et al., 2010). It is not clear if CLA amplifies the naturally occurring mobilization of body reserves and fatty acid accumulation when fed to dairy cows. Therefore, we investigated liver weight and adipose depot distribution in the present trial. Liver weight as a proportion of EBW was lower in the IG compared with all other 
groups. The liver weight increased until 42 DIM and continued to increase until 105 DIM. However, no differences between the control and CLA group were detected (Table 5). Andrew et al. (1994) slaughtered dairy cows at different physiological stages and measured liver weights of $6.08 \mathrm{~kg} 7 \mathrm{~d}$ before parturition and $10.34 \mathrm{~kg}$ after 63 DIM. The measured liver weights in the present trial were in the same range and support the view that the increase in liver weight is a normal physiological effect during early lactation.

The adipose depot distribution in the dairy cow is not well investigated. Due to CLA-induced decreases of adipose depots, which were observed in mice (DeLany et al., 1999; Tsuboyama-Kasaoka et al., 2000; Clément et al., 2002), we investigated how the adipose depots react under conditions of CLA feeding. For the 42/CLA and $42 / \mathrm{CON}$ group, the retroperitoneal adipose depot was decreased compared with the IG, but the decrease in the 42/CLA group only tended to be significant and the decrease was $14.3 \%$ lower in comparison with the decrease of the $42 / \mathrm{CON}$ group. After 105 DIM in the experiment, the retroperitoneal fat depot was decreased in the CLA and control group. This suggests a lipomobilization protective effect of CLA in the first 42 DIM. The retroperitoneal fat depot is the most sensitive depot in mice (DeLany et al., 1999) and the results of the present study indicate that this is the same in dairy cows. Effects of CLA on the weight of the omental, mesenteric, and s.c. adipose depot were not observed. Changes in the s.c. adipose depot over time were very small and no effect of CLA on the weight could be detected. Tsuboyama-Kasaoka et al. (2000) showed that s.c. fat in mice was decreased. In contrast, Harvatine et al. (2009) proved an increase in the expression of lipid synthesis enzymes in s.c. adipose tissue of cows during MFD.

The converse effects of CLA on dairy cows compared with mice might be due to 2 different reasons. The first reason could be the differences in fat metabolism of mice and ruminants (Pearce 1983) and the second could be the administrated doses. Doses from 0.01 to $0.05 \%$ CLA in the diet are sufficient for MFD. Negative effects on the liver weights and adipose depots as demonstrated in mice occurred at doses as high as 0.5 to $1.0 \%$ CLA in the diet (Bauman et al., 2008). The dose in the present trial was $0.04 \%$ trans-10, cis-12 CLA isomer in the diet relative to an average DMI of 15.3 $\mathrm{kg}$ in both periods. Furthermore, Bauman et al. (2008) concluded in their review that lower doses, as required for MFD, lead to different effects on the fat metabolism of adipose tissue in dairy cows than do higher doses and the results of our trial support this statement.

\section{CONCLUSIONS}

Dietary CLA supplementation in dairy cows decreased milk fat content and yield but showed no effect on daily milk energy output and calculated energy balance due to slightly increased milk yield and marginal decrease in DMI. The energy was repartitioned to higher milk synthesis. The decrease of EBW, adipose depots, and the increase in liver weight were interpreted to be typical for the early-lactating cows, whereas CLA effects were only marginal (retroperitoneal fat) or not detectable. The retroperitoneal adipose depot underwent the most pronounced alteration in early lactation and CLA decelerated this mobilization when compared with the unsupplemented CON group.

\section{ACKNOWLEDGMENTS}

The authors thank the Deutsche Forschungsgemeinschaft (DFG, Bonn, Germany) for financial support (PAK 286/1, DA 558/5-1). Furthermore, the assistance of the coworkers of the Institute of Animal Nutrition and the Experimental Station of the Friedrich-LoefflerInstitute (FLI) in Brunswick Germany, in performing the experiment and analyses, is gratefully acknowledged.

\section{REFERENCES}

Andrew, S. M., D. R. Waldo, and R. A. Erdman. 1994. Direct analysis of body composition of dairy cows at three physiological stages. J. Dairy Sci. 77:3022-3033.

Bauman, D. E., and W. B. Currie. 1980. Partitioning of nutrients during pregnancy and lactation: A review of mechanisms involving homeostasis and homeorhesis. J. Dairy Sci. 63:1514-1529.

Bauman, D. E., J. W. Perfield II, K. J. Harvatine, and L. H. Baumgard. 2008. Regulation of fat synthesis by conjugated linoleic acid: Lactation and the ruminant model. J. Nutr. 138:403-409.

Baumgard, L. H., B. A. Corl, D. A. Dwyer, A. Saebø, and D. E. Bauman. 2000. Identification of the conjugated linoleic acid isomer that inhibits milk fat synthesis. Am. J. Physiol. Regul. Integr. Comp. Physiol. 278:R179-R184.

Bell, A. W. 1995. Regulation of organic nutrient metabolism during transition from late pregnancy to early lactation. J. Anim. Sci. 73:2804-2819.

Bernal-Santos, G., J. W. Perfield II, D. M. Barbano, D. E. Bauman, and T. R. Overton. 2003. Production responses of dairy cows to dietary supplementation with conjugated linoleic acid (CLA) during the transition period and early lactation. J. Dairy Sci. 86:3218-3228.

Brömmel, C., U. Meyer, M. Wahner, and G. Flachowsky. 2007. Effect of conjugated linoleic acid (CLA) supplementation on milk yield and composition of dairy cows. Proc. Soc. Nutr. Physiol. 16:48 (Abstr.)

Castañeda-Gutiérrez, E., B. C. Benefield, M. J. de Veth, N. R. Santos, R. O. Gilbert, W. R. Butler, and D. E. Bauman. 2007. Evaluation of the mechanism of action of conjugated linoleic acid isomers on reproduction in dairy cows. J. Dairy Sci. 90:4253-4264.

Castañeda-Gutiérrez, E., T. R. Overton, W. R. Butler, and D. E. Bauman. 2005. Dietary supplements of two doses of calcium salts 
of conjugated linoleic acid during the transition period and early lactation. J. Dairy Sci. 88:1078-1089.

Clément, L., H. Poirier, I. Niot, V. Bocher, M. Guerre-Millo, S. Krief, B. Staels, and P. Besnard. 2002. Dietary trans-10, cis-12 conjugated linoleic acid induces hyperinsulinemia and fatty liver in the mouse. J. Lipid Res. 43:1400-1409.

Coffey, M. P., J. Hickey, and S. Brotherstone. 2006. Genetic aspects of growth of Holstein-Friesian dairy cows from birth to maturity. J. Dairy Sci. 89:322-329.

de Veth, M. J., J. M. Griinari, A. M. Pfeiffer, and D. E. Bauman. 2004. Effect of CLA on milk fat synthesis in dairy cows: Comparison of inhibition by methyl esters and free fatty acids, and relationships among studies. Lipids 39:365-372.

Degrace, P., L. Demizieux, J. Gresti, J.-M. Chardigny, J.-L. Sébédio, and P. Clouet. 2003. Association of liver steatosis with lipid oversecretion and hypotriglyceridaemia in C57BL/6j mice fed trans10, cis-12-linoleic acid. FEBS Lett. 546:335-339.

DeLany, J. P., F. Blohm, A. A. Truett, J. A. Scimeca, and D. B. West. 1999. Conjugated linoleic acid rapidly reduces body fat content in mice without affecting energy intake. Am. J. Physiol. 276:R1172R1179.

Edmonson, A. J., I. J. Lean, L. D. Weaver, T. Farver, and G. Webster. 1989. A body condition scoring chart for Holstein dairy cows. J. Dairy Sci. 72:68-78.

Flachowsky, G., K. Erdmann, L. Hüther, G. Jahreis, P. Möckel, and P. Lebzien. 2006. Influence of roughage/concentrate ratio and linseed oil on the concentration of trans-fatty acids and conjugated linoleic acid in duodenal chyme and milk fat of late lactating cows. Arch. Anim. Nutr. 60:501-511.

Flachowsky, G., P. Lebzien, and U. Meyer. 2004. Zur energetischen Futterbewertung bei Hochleistungskühen (Contribution to the energetic feed evaluation for high performing dairy cows). Übersichten zur Tierernährung 32:23-56.

Folch, J., M. Lees, and G. H. S. Stanley. 1957. A simple method for the isolation and purification of total lipides from animal tissues. J. Biol. Chem. 226:497-509.

Gaines, W. L. 1928. The energy basis of measuring milk yield in dairy cows. IL Agric. Exp. Sta. Bull. 308:401-438.

GfE (German Society of Nutrition Physiology). 1991. Leitlinien für die Bestimmung der Verdaulichkeit von Rohnährstoffen an Wiederkäuern (Guidelines for determining the digestibility of crude nutrients in ruminants). J. Anim. Physiol. Anim. Nutr. (Berl.) 65:229-234.

GfE (German Society of Nutrition Physiology). 2001. Empfehlungen zur Energie- und Nährstoffversorgung der Milchkühe und Aufzuchtrinder (Recommendations of Energy and Nutrient Supply for Dairy Cows and Breeding Cattle). DLG Verlag, Frankfurt am Main, Germany.

Grabherr, H., M. Spolders, M. Fürll, and G. Flachowsky. 2009. Effect of several doses of zeolite A on feed intake, energy metabolism and on mineral metabolism in dairy cows around calving. J. Anim. Physiol. Anim. Nutr. (Berl.) 93:221-236.

Grummer, R. R. 1993. Etiology of lipid-related metabolic disorders in periparturient dairy cows. J. Dairy Sci. 76:3882-3896.

Harvatine, K. J., J. W. Perfield II, and D. E. Bauman. 2009. Expression of enzymes and key regulators of lipid synthesis is upregulated in adipose tissue during CLA-induced milk fat depression in dairy cows. J. Nutr. 139:849-854.

Janssen, H. 2006. Untersuchungen zum Einfluß unterschiedlicher Fütterungsintensitäten auf das Körperwachstum, die Futteraufnahme, die Körperzusammensetzung sowie den Stoff- und Energieansatz von weiblichen Kälbern und Aufzuchtrindern (Studies on the influence of different feeding intensities on growth, feed intake, body composition as well as substance and energy retention of female calves and breeding cattle). PhD Dissertation. University of Göttingen, Cuvillier Verlag, Göttingen, Germany.

Jaudszus, A., P. Möckel, E. Hamelmann, and G. Jahreis. 2010 Trans-10, cis-12-CLA-caused lipodystrophy is associated with profound changes of fatty acid profiles of liver, white adipose tissue and erythrocytes in mice: Possible link to tissue-specific alterations of fatty acid desaturation. Ann. Nutr. Metab. 57:103-111.
Liermann, T., A.-M. Pfeiffer, and F. J. Schwarz. 2008. Effects and post-effects on performance and metabolic parameters of early lactation dairy cows to dietary rumen-protected CLA and rumen protected fat. Proc. Soc. Nutr. Physiol. 17:30. (Abstr.)

Liermann, T., and F. J. Schwarz. 2007. Effects on performance and metabolic parameters of early lactation dairy cows to dietary rumen-protected conjugated linoleic acid and propylene glycol. Proc. Soc. Nutr. Physiol. 16:18. (Abstr.)

Metzger-Petersen, K., K.-H. Südekum, M. Pries, and H. van de Sand 2008. Effects of feeding conjugated linoleic acids to dairy cows during the transition period and early lactation upon milk and milk component yields. Proc. Soc. Nutr. Physiol. 17:64. (Abstr.)

Moallem, U., H. Lehrer, M. Zachut, L. Livshitz, and S. Yacoby. 2010 Production performance and pattern of milk fat depression of high-yielding dairy cows supplemented with encapsulated conjugated linoleic acid. Animal 4:641-652.

Moore, C. E., H. C. Hafliger, O. B. Mendivil, S. R. Sanders, D. E. Bauman, and L. H. Baumgard. 2004. Increasing amounts of conjugated linoleic acid (CLA) progressively reduces milk fat synthesis immediately postpartum. J. Dairy Sci. 87:1886-1895.

Odens, L. J., R. Burgos, M. Innocenti, M. J. VanBaale, and L. H. Baumgard. 2007. Effects of varying doses of supplemental conjugated linoleic acid on production and energetic variables during the transition period. J. Dairy Sci. 90:293-305.

Pappritz, J., U. Meyer, R. Kramer, E.-M. Weber, G. Jahreis, J. Rehage, G. Flachowsky, and S. Dänicke. 2011. Effects of long-term supplementation of dairy cow diets with rumen-protected conjugated linoleic acids (CLA) on performance, metabolic parameters and fatty acid profile in milk fat. Arch. Anim. Nutr. 65:89-107.

Pearce, J. 1983. Fatty acid synthesis in liver and adipose tissue. Proc. Nutr. Soc. 42:263-271.

Perfield, J. W. II, G. Bernal-Santos, T. R. Overton, and D. E. Bauman. 2002. Effects of dietary supplementation of rumen-protected conjugated linoleic acid in dairy cows during established lactation. J. Dairy Sci. 85:2609-2617.

Perfield, J. W. II, A. L. Lock, A. M. Pfeiffer, and D. E. Bauman. 2004 Effects of amide-protected and lipid-encapsulated conjugated linoleic acid (CLA) supplements on milk fat synthesis. J. Dairy Sci. $87: 3010-3016$

SAS Institute. 2004. SAS/STAT 9.1 User's Guide. SAS Inst., Inc., Cary, NC.

Shingfield, K. J., D. E. Beever, C. K. Reynolds, S. K. Gulati, D. J. Humphries, B. Lupoli, G. Hervás, and M. J. Griinari. 2004. Effect of rumen protected conjugated linoleic acid on energy metabolism of dairy cows during early to mid-lactation. J. Dairy Sci. 87(Suppl. 1):307. (Abstr.)

Sigl, T., G. Schlamberger, H. Kienberger, S. Wiedemann, H. H. D. Meyer, and M. Kaske. 2010. Rumen-protected conjugated linoleic acid supplementation to dairy cows in late pregnancy and early lactation: Effects on milk composition, milk yield, blood metabolites and gene expression in liver. Acta Vet. Scand. 52:16.

Staufenbiel, R. 1997. Konditionsbeurteilung von Milchkühen mit Hilfe der sonographischen Rückenfettdickenmessung (Evaluation of body condition in dairy cows by ultrasonographic measurement of back fat thickness). Prakt. Tierarzt 78:87-92.

Tsuboyama-Kasaoka, N., M. Takahashi, K. Tanemura, H. J. Kim, T. Tange, H. Okuyama, M. Kasai, S. Ikemoto, and O. Ezaki. 2000. Conjugated linoleic acid supplementation reduces adipose tissue by apoptosis and develops lipodystrophy in mice. Diabetes 49:1534-1542.

Tyrrell, H. F., and J. T. Reid. 1965. Prediction of energy value of cow's milk. J. Dairy Sci. 48:1215-1223.

Universität Hohenheim-Dokumentationsstelle. 1997. DLG Futterwerttabellen Wiederkäuer (Feed Value Tables for Ruminants). 7th ed. DLG-Verlag, Frankfurt am Main, Germany.

VDLUFA. 1993. Handbuch der Landwirtschaftlichen Versuchs- und Untersuchungsmethodik (VDLUFA-Methodenbuch). Vol. III. Die chemische Untersuchung von Futtermitteln. VDLUFA-Verlag, Darmstadt. Germany.

Wang, Y., and P. J. H. Jones. 2004. Dietary conjugated linoleic acid and body composition. Am. J. Clin. Nutr. 79:1153S-1158S. 